\title{
Optimization of NPK combination for seed production of onion (Allium cepa) crop
}

\author{
Muhammad Saleem Jilani ${ }^{1}$, Faridullah ${ }^{1}$, Kashif Waseem ${ }^{1}$, \\ Muhammad Sohail Khan ${ }^{1}$, Mehwish Kiran ${ }^{1}$, Muhammad Amjad \\ Nadim $^{2 *}$, Saba Fatima ${ }^{1}$ and Tehseen Ali Jilani ${ }^{1}$ \\ 1. Department of Horticulture, Gomal University, Dera Ismail Khan-Pakistan \\ 2. Department of Agronomy, Gomal University, Dera Ismail Khan-Pakistan \\ *Corresponding author'semail: dramjad@gu.edu.pk
}

Citation

Muhammad Saleem Jilani, Faridullah, Kashif Waseem, Muhammad Sohail Khan, Mehwish Kiran, Muhammad Amjad Nadim, Saba Fatima and Tehseen Ali Jilani. Optimization of NPK combination for seed production of onion (Allium cepa) crop. Pure and Applied Biology. Vol. 8, Issue 2, pp1736-1743. http://dx.doi.org/10.19045/bspab.2019.80117

\begin{tabular}{llll}
\hline \hline Received: 16/02/2019 & Revised: 12/06/2019 & Accepted: 15/06/2019 & Online First: 20/06/2019 \\
\hline \hline
\end{tabular}

\section{Abstract}

Low productivity along with extensive usage of onion may cause shortage of this crop, as our country is facing high population problem. Mainly, there are two causes of low yield, lack of improved production technologies and poor quality of seed. Moreover, nutrient management is also an important aspect for getting higher yield. The current trial was conducted in RCBD with three replications and eight treatments. Treatments included different NPK fertilizer combinations i.e. $\mathrm{T}_{1}$ : Control, $\mathrm{T}_{2}$ : 30-20-00, $\mathrm{T}_{3}$ : 60-40-15, $\mathrm{T}_{4}: 90-60-30, \mathrm{~T}_{5}: 120-80-45, \mathrm{~T}_{6}$ : 150-100-60, $\mathrm{T}_{7}: 180-120-75, \mathrm{~T}_{8}: 210-140-90 \mathrm{~kg} \mathrm{NPK} \mathrm{ha}^{-1}$ and three replications. Data on multiple parameters viz. time to sprouting (days), number of shoots $\left(\right.$ plant $\left.^{-1}\right)$, leaf length $(\mathrm{cm})$, flowering stalk (plant $\left.{ }^{-1}\right)$, stalk length $(\mathrm{cm})$, number of flowers $\left(\right.$ umbel $\left.^{-1}\right)$, umbel diameter $(\mathrm{cm})$, 1000 -seed weight $(\mathrm{g})$, seed yield $\left(\mathrm{kg} \mathrm{ha}^{-1}\right)$ were collected and statistically analyzed. It was noticed that increment of fertilizer rates delayed sprouting but increased the number of shoots, leaf length, flowering stalks, length of flowering stalks, flowers (umbel ${ }^{-1}$ ) and umbel diameter in onion cv. Shah Alam. Highest fertilizer dose ( $\mathrm{T}_{8}: 210-140-90 \mathrm{~kg}$ NPK ha $\left.{ }^{-1}\right)$ showed its superiority by producing maximum shoots $\left(6.48\right.$ plant $\left.^{-1}\right)$, longest leaves $(41.20 \mathrm{~cm})$, longest flowering stalk $(67.10 \mathrm{~cm})$, flowers $\left(372.22 \mathrm{umbel}^{-1}\right)$, umbel diameter $(6.45 \mathrm{~cm})$, seed weight $(3.03 \mathrm{~g})$ and seed yield $\left(420.0 \mathrm{~kg} \mathrm{ha}^{-1}\right)$. But almost all these parameters were statistically similar with $\mathrm{T}_{7}$ : 180-120-75 $\mathrm{kg} \mathrm{NPK} \mathrm{ha}^{-1}$, hence, it is recommended that T7 and T8 should be used for getting maximum onion production.

Keywords: Allium cepa; Flowering stalk; NPK; Onion; Seed weight; Seed yield; Umbel

\section{Introduction}

Onion (Allium cepa L.) is one of the important vegetable crop of winter season which is used for consumption in raw and mature bulb stage [1]. It is considered the next most important vegetable after tomato among horticultural crops [2] and ranks first major exportation crop. People throughout the world appreciate it due to its distinctive flavor and medicinal properties $[3,4]$. Onion has an essential role in our daily diet as it is commonly used in nearly all food arrangements for their unique flavor [5] or their ability to enhance food flavors [6]. Onion is also favored for its diuretic, stimulant and anti-bacterial 
properties. Using onion reduces lipid and blood cholesterol level, thus, preventing heart diseases [7]. Extensive use, as well as lower yield of onion may cause a shortage of this crop, as our country is facing high population problem. The two leading causes of low yield are lack of improved production technologies and secondly poor quality of seed. Onion seed production mainly depends on quality of seeds, agronomic practices and, plant protection measures are taken to produce a healthy and vigorous crop. Among various agronomic practices, nutrient management through the use of fertilizers is considered as an important factor for seed production. Onion growth and yield are very much dependent upon the application of minerals [8]. Chemical fertilizers are an inorganic source which is admixed into the soil to provide essential nutrients for improved plant growth and development [9, 10]. For enhanced plant growth, bulb yield, quality of bulbs and good quality seeds, the use of nitrogen, phosphorus and potassium are considered as essential [11]. Being the most important and vital component of protein and nucleic acid, $\mathrm{N}$ availability is of prime importance for growing plants [12]. It is also an essential component of many biomolecules and is a part of some or many enzymes and coenzymes associated with chlorophyll synthesis, photosynthesis and crop yield development [13]. The beneficial effect of nitrogen application on onion yield was noted [14-18]. A significant increase in seed germination, flowering scape, umbel size and seed yield with $\mathrm{N}$-application at $120 \mathrm{~kg} \mathrm{ha}^{-1}$ was reported [19]. It was also obtained good onion growth at maximum (138 kg ha-1) N-level [20]. Likewise, phosphorus is also vital nutrient element that stimulates the development of root, increases the strength of stem, seed production, earlier and even crop maturity, improved crop quality having more resistance to diseases [21]. Increased seed production was recorded by using 80 and $60 \mathrm{~kg} \mathrm{N \& P}$, which increased No. of scape, umbel size, seeds $\left(\right.$ umbel $^{-1}$ ) and seed yield $\left(\right.$ plant $\left.^{-1}\right)$ [22]. In accordance, potassium regulates opening and closing of stomata during photosynthesis. It plays a vital role in protein synthesis, ionic balance, enzymes activation and adenosine triphosphate (ATP) production [23]. Hence, for the economic feasibility of onion, a balanced ratio of primary macro-nutrients (NPK) is prerequisite for better onion production. It was found that $80-60-40 \mathrm{~kg}$ NPK ha-1 resulted in more leaves and massive bulb production, which in turn produced highest onion yield [24]. While, an increment in onion plant growth, bulb quality and yield with the use of increased level of mineral fertilizers was also observed [25]. It was observed that application NPK (120-130$160 \mathrm{~kg} \mathrm{ha}^{-1}$ ) excelled onion bulb yield [26]. Owing to facts mentioned above, this research work was planned to determine the performance of onion (cv. Shah Alam) for better seed production under different NPK combinations.

\section{Materials and methods}

A research trial under field conditions was carried out to check the efficacy of multiple fertilizer combinations to onion (cv. Shah Alam) seed production at Agricultural Research Institute, Dera Ismail Khan, Pakistan, during 2015-16. A randomized complete block design was used to carry out experiment having eight different fertilizer combinations and three replications. Net plot size of $3 \mathrm{~m} \times 3 \mathrm{~m}(9$ $\mathrm{m}^{2}$ ) was maintained for carrying out the trial. Experimental field was prepared by plowing soil three times. Medium size (3-5 $\mathrm{cm}$ ) bulbs of onion (cv. Shah Alam) were planted in the last week of October, keeping a distance of 30 and $10 \mathrm{~cm}$ between successive rows and plants, respectively. The seed crop was harvested later on during mid of June 2015. All the required cultural practices were kept constant for all experimental plots. The detail of experimental treatments is given as under;

$\mathrm{T}_{1}$ : Control (no fertilizer)

$\mathrm{T}_{2}: 30-20-00 \mathrm{~kg} \mathrm{NPK} \mathrm{ha}^{-1}$

$\mathrm{T}_{3}: 60-40-15 \mathrm{~kg} \mathrm{NPK} \mathrm{ha}^{-1}$ 
$\mathrm{T}_{4}: 90-60-30 \mathrm{~kg} \mathrm{NPK} \mathrm{ha}^{-1}$

$\mathrm{T}_{5}: 120-80-45 \mathrm{~kg}$ NPK ha-1

$\mathrm{T}_{6}: 150-100-60 \mathrm{~kg}$ NPK ha-

$\mathrm{T}_{7}: 180-120-75 \mathrm{~kg}$ NPK ha-1

$\mathrm{T}_{8}: 210-160-90 \mathrm{~kg}$ NPK ha-1

Data on different parameters viz. time to sprouting, No. of shoots $\left(\right.$ plant $\left.^{-1}\right)$, leaf length $(\mathrm{cm})$, flowering stalks $\left(\right.$ plant $\left.^{-1}\right)$, stalk length $(\mathrm{cm})$, No. of flowers (umbel $\left.{ }^{-1}\right)$, umbel diameter $(\mathrm{cm}), 1000$-seed weight $(\mathrm{g})$ and seed yield $\left(\mathrm{kg} \mathrm{ha}^{-1}\right)$ were collected and analyzed statistically by computing analysis of variance [27] and least significant difference test was used to check differences among the treatment means, if any.

\section{Results and discussion \\ Time to sprouting}

Significant results were recorded for time to sprouting (Table 1) against different fertilizer combinations. Data analysis showed that increasing rate of NPK delayed sprouting as maximum days (17.50) were recorded in $\mathrm{T}_{8}$ (210-140-90) which was statistically similar to $\mathrm{T}_{7}$ (180-120-75) and $\mathrm{T}_{6}$ (150-100-60 kg NPK ha ${ }^{-1}$ ) showing 17.30 and 16.85 days to sprouting, respectively. Statistically, the results for days to sprouting recorded in $\mathrm{T}_{5}$ (120-80$45)$ and $\mathrm{T}_{4}\left(90-60-30 \mathrm{~kg} \mathrm{NPK} \mathrm{ha}^{-1}\right)$ were at par with each other by taking 16.20 and 15.50 days, respectively. Whereas, control plots $\left(\mathrm{T}_{1}\right)$ took shortest time (13.50 days) to sprout. It was observed that sprouting was progressively delayed with increment of fertilizers levels. Our results are resembled with Jilani [28] who also reported significant differences in sprouting initiation and completion with the application of different NPK levels to multiple varieties of onion. Similarly, Ali et al. [29] also found significant variations in days taken for bulb emergence due to various rates of $\mathrm{N} \& \mathrm{P}$ for onion seed production.

\section{Number of shoots (plant ${ }^{-1}$ )}

Significant variations existed in the number of a shoot (Table 1) due to the application of multiple fertilizer combinations. An increment in NPK levels increased the number of onion shoots as maximum shoots (6.48 plant $\left.^{-1}\right)$ were recorded in $\mathrm{T}_{8}$ (210-140$90 \mathrm{~kg}$ NPK ha-1). It was statistically similar to $\mathrm{T}_{7}(180-120-75), \mathrm{T}_{6}(150-100-60)$ and $\mathrm{T}_{5}$ (120-80-45 kg NPK ha-1) with 5.78, 5.13 and 5.00 shoots plant $^{-1}$, respectively. The results obtained in $\mathrm{T}_{2}$ (30-20-00), $\mathrm{T}_{3}$ (6040-15) and $\mathrm{T}_{4}$ (90-60-30 kg NPK ha-1) were statistically at par with each other by

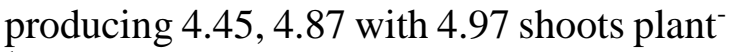
${ }^{1}$, respectively. Whereas, minimum shoots (4.27 plant $^{-1}$ ) were found in control plots where no fertilizer was applied. These findings conform with Khalid and Shedeed [30] who reported that the number of shoots increased under various levels of NPK. Similarly, Desuki et al. [25] and Abdissa et al. [14] also reported an increase in onion vegetative growth with an increase in mineral fertilizer application.

\section{Leaf length $(\mathbf{c m})$}

A progressive increment in leaf length was noticed with an increase in fertilizer rates. Significant variations existed in leaf length among the treatments (Table 1). The maximum leaf length $(41.20 \mathrm{~cm})$ was recorded in $\mathrm{T}_{8}$ (210-140-90). It was statistically similar with $\mathrm{T}_{7}$ (180-120-75) and $\mathrm{T}_{6}$ (150-100-60 kg NPK ha ${ }^{-1}$ ) which showed 39.00 and $38.15 \mathrm{~cm}$ long leaves, respectively. The results were found intermediate in $\mathrm{T}_{5}$ (120-80-45) and $\mathrm{T}_{4}$ (9060-30 kg NPK ha ${ }^{-1}$ ) with 37.00 and 35.60 $\mathrm{cm}$ longer leaves, respectively. The shortest leaves $(29.75 \mathrm{~cm})$ were obtained in plots grown without any fertilizer addition i.e. $\mathrm{T}_{1}$ (control). The result showed that leaf length increased when higher doses of NPK were applied. The reason for this might be the application of macro-nutrients at higher rates which played very efficiently in vegetative growth and leaf length. Jilani [28] and Pandey et al. [31] also reported significantly longest leaf blades by application of different doses of NPK to various cultivars of onion. Similarly, Adem and Tadesse [32] also reported an increase in leaf length in garlic when the higher doses of NP were used. 
Flowering stalks (plant ${ }^{-1}$ )

Although non-significant variations were observed among the treatments, however, an increasing trend in flowering stalks was observed (Table 1). Maximum flowering stalks (19.40 plant $\left.^{-1}\right)$ were recorded in $\mathrm{T}_{8}$ with highest NPK dose (210-140-90 kg NPK ha-1). The plots received no fertilizers i.e. $\mathrm{T}_{1}$ (control) showed un-fertilized plants and possessed lowest flowering stalks (15.60 plant $\left.^{-1}\right)$. It was reported by Alla et al. [33] that fertilizers application did not affect this trait as it is a genetic character. These results are also in affirmation with Yaso and Razak [34] who found almost similar results for number flower stalks as affected by different NPK combinations.

Table 1. Time to sprouting, number of shoots $\left(\right.$ plant $\left.^{-1}\right)$, leaf length $(\mathrm{cm})$, flowering stalks $\left(\right.$ plant $\left.^{-1}\right)$ and stalk length $(\mathrm{cm})$ of onion as affected by different NPK fertilizers combinations (Means followed by similar letter(s) do not differ significantly at $5 \%$ level of significance)

\begin{tabular}{|c|c|c|c|c|c|}
\hline $\begin{array}{l}\text { NPK fertilizer } \\
\text { combinations } \\
\left(\mathrm{kg} \mathrm{ha}^{-1}\right)\end{array}$ & $\begin{array}{l}\text { Time to } \\
\text { sprouting }\end{array}$ & $\begin{array}{l}\text { No. of shoots } \\
\quad\left(\text { plant }^{-1}\right)\end{array}$ & $\begin{array}{l}\text { Leaf length } \\
\quad(\mathrm{cm})\end{array}$ & 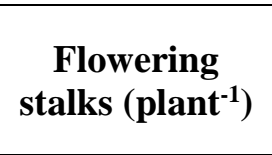 & $\begin{array}{l}\text { Stalk length } \\
\quad(\mathrm{cm})\end{array}$ \\
\hline $\mathrm{T}_{1}:$ Control & $13.50 \mathrm{f}$ & $4.27 \mathrm{c}$ & $29.75 \mathrm{~h}$ & 15.60 & $55.07 \mathrm{c}$ \\
\hline $\mathrm{T}_{2}: 30-20-00$ & 14.20 ef & $4.45 \mathrm{bc}$ & $31.00 \mathrm{~g}$ & 16.65 & $55.40 \mathrm{c}$ \\
\hline $\mathrm{T}_{3}: 60-40-15$ & $14.80 \mathrm{de}$ & $4.84 \mathrm{bc}$ & $33.50 \mathrm{f}$ & 17.00 & $55.55 \mathrm{c}$ \\
\hline $\mathrm{T}_{4}: 90-60-30$ & $15.50 \mathrm{~cd}$ & $4.97 \mathrm{bc}$ & $35.60 \mathrm{e}$ & 17.55 & $56.10 \mathrm{c}$ \\
\hline $\mathrm{T}_{5}: 120-80-45$ & $16.20 \mathrm{bc}$ & $5.00 \mathrm{abc}$ & $37.00 \mathrm{~d}$ & 18.25 & $57.73 \mathrm{c}$ \\
\hline $\mathrm{T}_{6}: 150-100-60$ & $16.85 a b$ & $5.13 \mathrm{abc}$ & $38.15 \mathrm{c}$ & 18.30 & $59.68 \mathrm{bc}$ \\
\hline $\mathrm{T}_{7}: 180-120-75$ & $17.30 \mathrm{ab}$ & $5.78 \mathrm{ab}$ & $39.00 \mathrm{~b}$ & 18.50 & $65.93 \mathrm{ab}$ \\
\hline $\mathrm{T}_{8}: 210-140-90$ & $17.50 \mathrm{a}$ & $6.48 \mathrm{a}$ & $41.20 \mathrm{a}$ & 19.40 & $67.10 \mathrm{a}$ \\
\hline $\mathbf{L S D}_{0.05}$ & 1.16 & 1.50 & 0.79 & NS & 7.41 \\
\hline $\begin{array}{c}\text { NPK fertilizer } \\
\text { combinations } \\
\left(\mathrm{kg} \mathrm{ha}^{-1}\right)\end{array}$ & $\begin{array}{c}\begin{array}{c}\text { No. of } \\
\text { flowers } \\
\left(\text { umbel }^{-1}\right)\end{array} \\
\end{array}$ & $\begin{array}{c}\text { Umbel } \\
\text { diameter } \\
(\mathbf{c m})\end{array}$ & \multicolumn{2}{|c|}{ 1000-seed weight (g) } & $\begin{array}{c}\text { Seed yield } \\
\left(\mathrm{kg} \mathrm{ha}^{-1}\right)\end{array}$ \\
\hline $\mathrm{T}_{1}:$ Control & $266.61 \mathrm{e}$ & $4.35 \mathrm{~d}$ & \multicolumn{2}{|c|}{$2.73 \mathrm{~d}$} & $194.20 \mathrm{~g}$ \\
\hline $\mathrm{T}_{2}: 30-20-00$ & $278.20 \mathrm{de}$ & $4.92 \mathrm{c}$ & \multicolumn{2}{|c|}{$2.78 \mathrm{~d}$} & $232.50 \mathrm{f}$ \\
\hline $\mathrm{T}_{3}: 60-40-15$ & $285.00 \mathrm{~d}$ & $4.96 \mathrm{c}$ & \multicolumn{2}{|c|}{$2.84 \mathrm{c}$} & $270.00 \mathrm{e}$ \\
\hline $\mathrm{T}_{4}: 90-60-30$ & $302.50 \mathrm{c}$ & $5.54 \mathrm{~b}$ & \multicolumn{2}{|c|}{$2.86 \mathrm{c}$} & $325.80 \mathrm{~d}$ \\
\hline $\mathrm{T}_{5}: 120-80-45$ & $315.70 \mathrm{c}$ & $5.65 \mathrm{~b}$ & \multicolumn{2}{|c|}{$2.92 \mathrm{~b}$} & $360.50 \mathrm{c}$ \\
\hline $\mathrm{T}_{6}: 150-100-60$ & $345.60 \mathrm{~b}$ & $5.88 \mathrm{~b}$ & \multicolumn{2}{|c|}{$2.96 \mathrm{~b}$} & $385.00 \mathrm{~b}$ \\
\hline $\mathrm{T}_{7}: 180-120-75$ & $366.22 \mathrm{a}$ & $5.87 \mathrm{~b}$ & \multicolumn{2}{|c|}{$3.05 \mathrm{a}$} & $410.20 \mathrm{a}$ \\
\hline $\mathrm{T}_{8}: 210-140-90$ & $372.22 \mathrm{a}$ & $6.45 \mathrm{a}$ & \multicolumn{2}{|c|}{$3.03 \mathrm{a}$} & $420.00 \mathrm{a}$ \\
\hline $\mathbf{L S D}_{0.05}$ & 15.33 & 0.52 & \multicolumn{2}{|c|}{0.05} & 16.25 \\
\hline
\end{tabular}




\section{Length of flowering stalks $(\mathbf{c m})$}

The perusal of data presented in (Table 1) revealed that multiple fertilizers combinations increased the length of flowering stalks. The most extended flowering stalks $(67.10 \mathrm{~cm})$ were obtained in $\mathrm{T}_{8}$ (210-140-90) which was statistically akin with $\mathrm{T}_{7}$ (180-120-75) and $\mathrm{T}_{6}$ (150-100$60 \mathrm{~kg} \mathrm{NPK} \mathrm{ha}^{-1}$ ) by producing $65.93 \mathrm{~cm}$ and $59.68 \mathrm{~cm}$ long flowering stalks, respectively. It was also observed that the results from T1 up to T5 were statistically at par with each other showing no significance. Enhancement of flowering stalks length with the application of NPK fertilizers at higher rates indicated that adequate supply of macro-nutrients improved flower characteristics of onion (cv. Shah Alam) in agro-ecology of Dera Ismail Khan. Our results are supported by Jilani [28] who also reported longer flowering stalks by application of different doses of NPK fertilizers to different varieties of onion. Similarly, Abas et al. [35] also reported a maximum length of the flowering stalk with a higher doze of $\mathrm{N}$ application.

\section{Number of flowers (umbel-1)}

Significant variations observed in the number of flowers due to variable application of NPK fertilizers (Table 1). The results showed an increased number of flowers with increased rates of NPK, as maximum flowers (372.22 umbel $\left.^{-1}\right)$ was recorded in $\mathrm{T}_{8}$ (210-140-90) followed by $\mathrm{T}_{7}$ (180-120-75 kg NPK ha-1) which produced 366.22 flowers umbel $^{-1}$ and both treatments were statistically alike. Statistically, similar response for flowers was found in $\mathrm{T}_{5}$ (12080-45) and $\mathrm{T}_{4}$ (90-60-30 kg NPK ha-1) with 315.70 and 302.50 flowers umbel $^{-1}$, respectively. While the minimum number of flowers (266.61 umbel ${ }^{-1}$ ) was observed in un-fertilized plants $T_{1}$ (control) which differed significantly from all other treatments except $\mathrm{T}_{2}(30-20-00 \mathrm{~kg}$ NPK ha$\left.{ }^{1}\right)$ which produced 278.20 flowers umbel $^{-1}$. Similar findings were reported by Ali et al. [29] and Abas et al. [35] who recorded greater number of flowers by application of different doses of NK.

\section{Umbel diameter (cm)}

Results pertaining to umbel diameter expressed significant differences with multiple fertilizer combinations (Table 1). An increased rate of NPK in $\mathrm{T}_{8}$ (210-140$90 \mathrm{~kg} \mathrm{ha}^{-1}$ ) produced significantly maximum umbel diameter $(6.45 \mathrm{~cm})$. It was followed by $\mathrm{T}_{7}$ (150-100-60), $\mathrm{T}_{6}$ (180-120$75), \mathrm{T}_{5}(120-80-45)$ and $\mathrm{T}_{4}(90-60-30 \mathrm{~kg}$ NPK ha ${ }^{-1}$ ) with $5.88,5.87,5.65$ and $5.54 \mathrm{~cm}$ umbel diameter, respectively. All these treatments were statistically non-significant with each other. The un-fertilized plants in $\mathrm{T}_{1}$ (control) produced minimum umbel diameter $(4.35 \mathrm{~cm})$ which also differed statistically from all other treatments. Statistically, similar umbel diameter of 4.92 and $4.96 \mathrm{~cm}$ were recorded in $\mathrm{T}_{2}(30-20-00)$ and $\mathrm{T}_{3}$ (60-40-15 kg NPK $\left.\mathrm{ha}^{-1}\right)$, accordingly. Our results resemble with Bhardwaj [22] who also found increased onion umbel diameter with augmented fertilizer applications. Likewise, Ali et al. [29] also recorded greater umbel diameter and highest fruits set per umbel with implementation of different doses of NK.

\section{0-seed weight (g)}

Data given in (Table 1) showed that thousand seed weight increased with an increase in nutrients (NPK) application. Maximum seed weight $(3.05 \mathrm{~g})$ was achieved in $\mathrm{T}_{7}$ (180-120-75) which was very closely followed by $\mathrm{T}_{8}(210-140-90 \mathrm{~kg}$ NPK ha ${ }^{-1}$ ) which produced of $3.03 \mathrm{~g}$ seed weight, while both treatments were significantly similar with each other. Likewise, results recorded in $\mathrm{T}_{6}(150-100-$ $60)$ and $T_{5}$ (120-80-45) also showed statistically similar seed indices (2.96 and $2.92 \mathrm{~g})$, respectively. The minimum seed weight $\left(2.73 \mathrm{~g}\right.$ ) was achieved in $\mathrm{T}_{1}$ (control) which was at par with $\mathrm{T}_{2}$ (30-20-00) producing $2.78 \mathrm{~g}$ seed weight. These findings are supported by Ali et al. [29] who reported significant variations (2.87 to $3.01 \mathrm{~g}$ ) in thousand seed index. Similarly, Gasim and George [36] reported significant effect on seed quality due to NPK 
application. Increased seed weight in highest NPK treatments might be due to more availability of nutrients that produced, healthy and heavier seeds $[37,38]$.

\section{Seed yield $\left(\mathrm{kg} \mathrm{ha}^{-1}\right)$}

Data analysis revealed that fertilizer combinations enhanced onion seed yield (Table 1). Highest seed yield (420 kg ha-1) was achieved by using higher NPK dose $\mathrm{T}_{8}$ (210-140-90) which was very closely followed by $\mathrm{T}_{7}$ (180-120-75 kg NPK ha-1) producing seed yield of $410 \mathrm{~kg} \mathrm{ha}^{-1}$ and both treatments were statistically identical. Minimum (194 $\mathrm{kg} \mathrm{ha}^{-1}$ ) seed yield was achieved from control plots $\left(\mathrm{T}_{1}\right)$ which differed significantly from all other treatments. Enhancement in seed yields was recorded by Ali et al. [29] with the addition of multiple levels of N and K. Similarly, higher seed yield with the application of varying doses of NPK was observed by Aminpour et al. [39]. However, Ayala et al. [40] reported higher seed yield with the application of NPK @ 153-37-14 kg ha ${ }^{-1}$. The possible reason of this yield increase be the maximum length of leaves. It promoted the photosynthetic activities and efficient utilization of photosynthates from leaves to reproductive parts of plant. This improvement resulted in enhanced seed fillings with better and more number of flowers per umbel, thus, resulting in maximum seed yield [41].

\section{Conclusion}

The results of the current experiment indicated that application of NPK proved beneficial for onion seed yield. It is concluded that the application of 180-120-75 kg NPK ha ${ }^{-1}$ should be appropriate for obtaining increased and profitable seed yield of onion under the agroecology of Dera Ismail Khan, Pakistan. Moreover, the use of 210-140-90 kg NPK hais also a viable option for getting maximized production of onion, if the prices of different inputs and fertilizers are reasonable.

\section{Authors' contributions}

Conceived and designed the experiments: $\mathrm{S}$ Jilani \& Faridullah, Performed the experiments: S Jilani \& Faridullah, Analyzed the data: S Fatima, M Kiran \& TA Jilani, Statistical analysis: MA Nadim, Wrote the paper: M Sohail \& K Waseem

\section{Acknowledgements}

This study was carried out at the Agricultural Research Institute, Dera Ismail Khan, Pakistan. The authors are thankful to Mr. Kazim Shah, Director and Mr. Abdul Qayyum Khan, Horticulturist for their cooperation and providing opportunities to conduct the research experiment.

\section{References}

1. Mahanthesh B, Sajjan RPM, Harshavardhan M, Vishnuvardhana \& Janardhan G (2008). Evaluation of different onion genotypes for yield and processing quality parameters in kharif under irrigated condition. The Asian $J$ Hort 3(1): 5-9.

2. Griffiths $\mathrm{G}$, Trueman L Crowther T, Thomas B \& Smith B (2002). Onions-a global benefit to health. Phytotherap Res 16: 603-615.

3. Padmini K, Gowda VR \& Naik LB (2007). Studies on parental synchronization in flowering for hybrid seed production in onion. J Hort Sci 2(1): 4749.

4. Tyagi AK \& Yadav SK (2007). Effect of growth regulators on growth and yield of onion (Allium cepa L.) cv. Pusa Red. Plant Arch 7(1): 371-372.

5. Hossain AKMA \& Islam J (1994). Status of Allium production in Bangladesh. Acta Hort 358: 33-36.

6. Randle WM (2000). Increasing nitrogen concentration in hydroponic solution affects onion flavors and bulb quality. J Amer Soc Hort Sci 12(5): 254259.

7. Sharangi AB \& Datta S (2005). Medicinal properties of spices. Indian $J$ Arecanut Spices and Medicinal Plants 7: 42-49.

8. Devlin RM \& Witham FH (1986). Plant physiology. $4^{\text {th }}$ Ed. CBS Pub \& Dist, 485, Jain Bhawan, Shadhara, Delhi, 110032, India.

9. Ginindza TK, Masarirambi MT, Wahome PK \& Oseni TO (2015). 
Effects of different concentrations of NPK fertilizers on growth and development of wild okra (Corchorus olitorius). Agric Biol J N Am 6(3): 7480.

10. Masarirambi MT, Mbokazi MB, Wahome PK \& Oseni TO (2012). Effects of kraal manure application rates on growth and yield of wild okra (Corchorus olitorius L.) in a subtropical environment. Asian J Agric Sci 4 (1): 89-95.

11. Brewster JL (1994). Onions and other vegetable Alliums. $\mathrm{CAB}$ Intl., Wallingford, UK, pp 236.

12. Naruka IS, Singh PP, Rathore SS \& Singh M (2005). Response of garlic cultivars to nitrogen fertilization and crop geometry on composition of bulb. Proceedings of National Seminar on Agro- Technology, Quality, processing and export of Spices at JNKVV, March 20-21, Jabalpur, pp 52.

13. Eckert D (2010). Efficient fertilizer use of nitrogen, pp 1-19.

14. Abdissa Y, Tekalign T \& Pant LM (2011). Growth, bulb yield and quality of onion as influenced by nitrogen and phosphorus fertilization on vertisol growth attributes, biomass production and bulb yield. Afric J Agric Res 6(14): 3252-3258.

15. Devi AK, Limi A \& Singh NG (2003). Effects of inorganic and bio fertilizers on bulb yield and economics of multiplier onion (cv. Aggregatum Don). Newsletter National. Hort Res Dev Fund 23(3): 1-3.

16. Mahmood AF, Hosna FA \& Yousef BDS (2000). Effect of organic and inorganic fertilizers on onion crop. $J$ Agric Sci Mansoura Univ 25(9): 58135829.

17. Mawgoud ARA, Hussein ASR \& Nemr MAE (2005). Interactive effects of zinc and different nitrogen sources on yield and quality of onion. Arab-Univ J Agric Sci 13(3): 863-875.

18. Tiwori RS, Ankur A \& Sengar SC (2002). Effect of doses and methods of nitrogen application on growth, bulb yield and quality of "Pusa Red" onion (Allium cepa L.). Indian J Agri Sci 72(1): 23-25.

19. Mishra HP (1994). Effect of nitrogen and potassium on onion seed production in calcareous soil. $J$ Potassium Res 10: 236-241.

20. Gessesew WS, Woldetsadik K \& Mohammed W (2015). Growth parameters of onion as affected by nitrogen fertilizer rates and intra-row spacing under irrigation in Gode, South-Eastern Ethiopia. Agric Forestry and Fish 4(6): 239-245.

21. Uwah DF, Nwagwu FA \& Iwo GA (2010). Response of okra to different rates of nitrogen and lime on an acid soil”. Inter J Agric Sci 2(2): 14-20.

22. Bhardwaj ML (1991). Influence of bulb size and plant spacing on seed production in onion (Allium cepa L.) Prog Hort 23: 76-79.

23. Prajapati T \& Modi A (2012). The importance of Potassium in plant growth-A review. Indian J Plant Sci 1(2-3): 177-186.

24. Deho NA, Wagan MR, Baloch MK, Rajpar I \& Keerio MI (2002). NPK trail on onion (Allium cepa L.). Pak J Applied Sci 2(8): 820-821.

25. Desuki E, Asmaa M, Mahmoud R \& Hafiz MM (2006). Response of onion plants to minerals and bio-fertilizers application. Res J Agri Biological Sci 2(6): 292-298.

26. Islam MK, Alam MF \& Islam AKMR (2007). Growth and yield response of onion genotypes to different levels of fertilizers. Bangladesh J Bot 36(1): 3338. 
27. Steel RGD, Torrie JH \& Dickay DA (1997). Principles and procedures of statistics-a biometric approach. $3^{\text {rd }} \mathrm{Ed}$. McGraw-Hill Publish Co. Toronto, Canada.

28. Jilani MS (2004). Studies on the management strategies for bulb and seed production of different cultivars of onion. Ph.D. Dissert. Gomal Univ. D.I. Khan, Pakistan.

29. Ali MK, Alam MF, Alam MN, Islam MS \& Khandaker SMAT (2007). Effect of nitrogen and potassium levels on yield and quality seed production of onion. J Applied Sci Res 3(12): 18891899.

30. Khalid A \& Shedeed MR (2015). Effect of NPK and foliar nutrition on growth, yield and chemical constituents in Nigella sativa L. J Mater Environ Sci 6(6): 1709-1714.

31. Pandey VK, Sanjay K Yadav YV (2012). Effect of nitrogen, phosphorus and potash on growth, yield and yield components in garlic. Inter J Plant Sci 7(1): 71-73.

32. Adem BE \& Tadesse ST (2014). Evaluating the role of nitrogen and phosphorus on the growth and performance of garlic. Asian J Agric Res 8(4): 211-217.

33. Alla MHH, Kafoury AKE, Ibrahim MY \& Gammal MME (1991). Effect of nitrogen fertilizer levels on bulb yield and quality of some onion cultivars. Minufiya J Agric Res, 16 (2): 16371644.

34. Yaso IA \& Razak HSA (2007). Effect of NPK fertilization on bulb yield and quality of onion under reclaimed calcareous soil. J Agric Environ Sci 6(1): 225-242.
35. Abas SIE, Ali AM, Mohamed OE \& Nourai, AH (2016). Effects of nitrogen fertilization and bulb spacing on 'Saggai Red' onion seed production in Berber area of River Nile State, Sudan. Acta Hort 1143: 235-244.

36. Gasim AAEA \& George RAT (2007). Effect of mineral nutrition on seed yield and quality in onion. ISHS Acta Hort 143: 8 .

37. Lamo K (2009). Effect of organic and bio-fertilizers on seed production of radish (Raphanus sativus $\mathrm{L}$ ) $\mathrm{cv}$. Chinese Pink. MSc thesis, Dr. Y.S. Parmar Univ. Hort. \& Forestry, Nauni, Solan, HP, India.

38. Mehta KS (2010). Integrated nutrient management studies on growth, seed yield and quality of radish (Raphanus sativus L.) cv. Chinese Pink. M.Sc thesis. Dr. Y.S. Parmar Univ. Hort. \& Forestry, Nauni, Solan, HP, India.

39. Aminpour A, Yahyeabadi M \& Gafari A (2007). Effect of time and rate of $\mathrm{N}$ and $\mathrm{K}$ application on seed yield, yield component and seed germination percent and rate of onion (cv. Texas Early Grano-502). Pajouhesh and Sazandegi 19(4): 185-192.

40. Ayala G, Oscar J, Estrada G, Julio A, Hernandez LA, Gomez M \& Hector E (1996). Effect of fertilization on onion seed production, yield and physical quality. $16^{\text {th }}$ Congreso de Fitogenetica, Texacoco, Mexico, pp 11-16.

41. Panwar AS, Raiyan JS Verma VS (2000). Yield and quality of radish seeds as affected by fertility levels and bio-fertilizers. Indian J Agron 45(4): 822-826. 